\title{
Marcin Kowalewski
}

Uniwersytet Ekonomiczny we Wrocławiu

e-mail: marcin.kowalewski@ue.wroc.pl

\section{Marcin Czyczerski}

Grupa CCC SA

\section{ZARZĄDZANIE DOKONANIAMI W SPÓLCE HANDLOWEJ \\ PERFORMANCE MANAGEMENT SYSTEM IN THE RETAIL COMPANY}

\section{DOI: $10.15611 /$ pn.2018.514.18}

JEL Classification: M210

Streszczenie: Współczesne systemy zarządzania dokonaniami stanowią integralną część systemu informacyjnego i kontrolnego przedsiębiorstwa. Wraz z rozwojem systemów Business Intelligence nastąpiła istotna zmiana możliwości zarządzania dokonaniami, zwłaszcza w raportowaniu zarządczym wykorzystującym w coraz większym zakresie potencjał kokpitów menedżerskich. Podstawowym celem niniejszego artykułu jest przedstawienie procesu projektowania i wdrażania systemu zarządzania dokonaniami w jednej z największych spółek handlowych działających przede wszystkim na terenie Europy Środkowej i Wschodniej. W pierwszej części artykułu zostaną zaprezentowane uwarunkowania teoretyczne współczesnego systemu zarządzania dokonaniami oraz wykorzystanie w nich systemu Business Intelligence (BI). Następnie autorzy odniosą się do fazy projektowania i wdrażania tego systemu w prezentowanym podmiocie, przede wszystkim w jego dziale sprzedaży.

Słowa kluczowe: zarządzanie dokonaniami, Business Intelligence, kokpity menedżerskie, spółka handlowa.

Summary: Performance management is an integral part of the enterprise's information and control system. The development of Business Intelligence systems enables relevant changes of performance management. It refers especially to management reporting where managers can use the big potential of dashboards nowadays. The main aim of this paper is the presentation and critical analysis of designing and implementing processes of performance management system to one of the biggest retail companies in Central and Eastern Europe. The first part of the article will present the theoretical aspects of the modern performance management system and the use of the Business Intelligence (BI) in them. Next, the authors will refer to the design and implementation phase of this system in the retail company, primarily in its sales department.

Keywords: perfomance management, Business Intelligence, performance dashboards, retail company. 


\section{Wstęp}

Zmienność sytuacji gospodarczej stała się normą. Prawie każdy artykuł naukowy z zakresu zarządzania, finansów czy ekonomii już na wstępie odwołuje się do wciąż rosnącej złożoności, konkurencji i ryzyka działalności gospodarczej. Biznes coraz mocniej zaskakuje innowacyjnością. W przemyśle mówi się o kolejnej rewolucji, nazywanej „Industrie 4.0”. To samo zjawisko implikuje konieczność poszukiwania rozwiązań, które pozwalają na przejrzyste komunikowanie i monitorowanie kierunku działania organizacji. Potrzeby współczesnego biznesu powodują, że zarządzanie dokonaniami na stałe weszło w pejzaż współczesnego świata biznesu, zarówno w aspekcie teoretycznym, jak i praktycznym [Czyczerski 2016].

XXI wiek jest nazywany wiekiem informacji. Analizując współczesny rynek biznesowy, można zaobserwować dynamiczny rozwój różnorodnych systemów informacyjnych wspomagających zarządzanie. Generowanie wartościowych informacji wspomagających skuteczne podejmowanie decyzji na różnych szczeblach przedsiębiorstwa jest jednym z podstawowych obszarów zainteresowania współczesnej rachunkowości zarządczej i controllingu. Aktualny rozwój systemów zarządzania dokonaniami przedsiębiorstw również wyraźnie wpisuje się w ten trend [Kowalewski 2016]. Podstawowym celem niniejszego artykułu jest przedstawienie procesu projektowania i wdrażania systemu zarządzania dokonaniami $\mathrm{w}$ jednej $\mathrm{z}$ największych spółek handlowych działających przede wszystkim na terenie Europy Środkowej i Wschodniej. W pierwszej części artykułu zostaną zaprezentowane uwarunkowania teoretyczne współczesnego systemu zarządzania dokonaniami oraz wykorzystanie w nich systemów Business Intelligence (BI). Następie autorzy odniosą się do fazy projektowania i wdrażania tego systemu w prezentowanym podmiocie, koncentrując się przede wszystkim na dziale sprzedaży, który stanowił priorytet $\mathrm{w}$ omawianym projekcie.

\section{Współczesne zarządzanie dokonaniami a systemy Business Intelligence}

Jak w przypadku każdej popularnej koncepcji z zakresu zarządzania wypracowano wiele definicji zarządzania dokonaniami (Performance Management). Cokins określa ją jako metodę przekładania strategicznych planów na rezultaty. Wspiera ona dokonania pracowników, ich rozwój i osiąganie sukcesów ekonomicznych. Aby było to jednak możliwe, kluczowe jest zaangażowanie wszystkich ról w organizacji. Wyzwala ono zachowania, które prowadzą do działań ukierunkowanych na realizację celów jednostek, zespołów, wydziałów, a w konsekwencji całego przedsiębiorstwa [Cokins 2009, za: Czyczerski 2016]. Ponadto warto zauważyć, że siłą koncepcji zarządzania dokonaniami jest integracja wszystkich istotnych narzędzi z obszaru zarządzania, szczególnie rachunkowości zarządczej i controllingu, takich jak mapo- 
wanie strategii, rachunek kosztów, budżetowanie, raportowanie, prognozowanie i wiele innych. Pozwala to na ich efektywniejsze wykorzystanie, np. w analizach predykcyjnych czy kontroli dokonań przedsiębiorstwa [Cokins 2009, za: Wierzbiński 2016a]. Definiując zarządzanie dokonaniami, można wyróżnić kluczowe obszary, do których ten system się odnosi [Broadbent, Laughlin 2009, za: Kowalewski 2016]:

- $\quad$ spójne powiązanie strategii z zarządzaniem operacyjnym, które jest często piętą achillesową wielu współczesnych organizacji, ze szczególnym ujęciem budżetowania,

- ciągłe udoskonalanie strategii, procesów i obszarów działalności w oparciu o informacje pochodzące z systemu zarządzania dokonaniami,

- $\quad$ skuteczne komunikowanie pracownikom wszystkich szczebli, na czym powinni się koncentrować w swojej pracy i za co będą premiowani,

- ciągłe monitorowanie dokonań przedsiębiorstwa, ustalanie przyczyn odchyleń występujących w różnych obszarach pomiaru oraz wprowadzanie działań korygujących.

Analizując przyczyny problemów organizacji w osiąganiu oczekiwanych wyników, na pierwszym miejscu należy wymienić: brak określenia i monitorowania celów strategicznych oraz akceptowanie ignorowania przez pracowników i kierownictwo strategii organizacji [Cokins 2009, s. 3-5]. Z pewnością nie są to jedyne problemy, ale ich występowanie gwałtownie ogranicza szansę na ekonomiczny sukces. Zarządzanie dokonaniami ułatwia definiowanie kierunku działania i wyzwala energię zespołów i jednostek. Powodzenie w stosowaniu tej koncepcji wymaga spełnienia istotnych warunków. Są one niezwykle ważne, zarówno na etapie budowania, jak i funkcjonowania systemu zarządzania dokonaniami. Po pierwsze, powodzenie zależy od wkomponowania tej koncepcji w szerszy kontekst działalności organizacji i powiązania jej ze strategią przedsiębiorstwa. Właściwie należy wskazać, że dla osiągnięcia wysokiej sprawności zarządzania dokonaniami konieczne jest wbudowanie go w strategię. Po drugie, wyniki stosowania tej koncepcji zależą od jakości procesu doboru odpowiednich dla organizacji mierników. Zjawiskiem niezwykle częstym w organizacjach, które połknęły bakcyla „dashbordów”, „tracho”, „pulpitów”, jest ogromna rozbudowa systemu mierników, swoista „mania KPI”. Wynika ona po części z braku umiejętności koncentrowania się na kluczowych czynnikach sukcesu, jak również z faktu, że organizacje bywają po prostu ich nieświadome. Dlatego niezwykle ważny jest dobór i zbalansowanie wykorzystywanych mierników. W tym przypadku balansowanie oznacza dobranie ich w odniesieniu do różnych istotnych aspektów i perspektyw działalności przedsiębiorstwa [Czyczerski 2016].

Trudno dzisiaj omawiać zarządzanie dokonaniami bez odwoływania się do systemu Business Intelligence (BI). Można przytoczyć wiele różnych definicji systemu Business Intelligence. Najłatwiej określić go, odwołując się do jego funkcji i elementów składowych. M. Łada i W. Burnet-Wyrwa definiują Business Intelligence 
jako rozwiązania informatyczne łączące tzw. hurtownie danych i zestawy narzędzi do przekształcania danych w użyteczną, praktyczną informację biznesową [Łada, Burnet-Wyrwa 2015, s. 134]. Według J. Nesteraka system BI to proces, który przekształca dane źródłowe w informacje, a te z kolei w wiedzę służącą zwiększeniu konkurencyjności przedsiębiorstwa. Inaczej można stwierdzić, że jest to zestaw narzędzi i metod pozwalających menedżerom różnych szczebli przedsiębiorstwa na zapewnienie pełnej integracji posiadanego zbioru danych, zapewnienie podwładnym instrumentarium ich analizy i wizualizacji zgodnie ze zmiennymi potrzebami oraz współdzielenie jej wyników przy zachowaniu z jednej strony bezpieczeństwa, a z drugiej wydajności [Nesterak 2015, s. 206, za: Kowalewski, Czyczerski 2018].

S. Negash określa Business Intelligence jako połączenie gromadzenia danych, przechowywania danych i zarządzania wiedzą z narzędziami analitycznymi do prezentacji złożonych wewnętrznych i zewnętrznych informacji wspierających planowanie i proces podejmowania decyzji. Według tej definicji system BI powinien zapewnić dostarczanie praktycznych informacji we właściwym czasie, we właściwym miejscu i we właściwej formie, aby pomagać decydentom w przedsiębiorstwie [Negash 2004, s. 178]. Warto podkreślić, że wykorzystanie systemów BI zupełnie zmieniło też oblicze zarządzania dokonaniami. Dotyczy to przede wszystkim możliwości zautomatyzowanego gromadzenia, integracji oraz analizy ogromnych zbiorów danych pochodzących z różnorodnych systemów zarówno wewnętrznych, jak i zewnętrznych przedsiębiorstwa, a także transformacji tych danych w wartościowe informacje oraz skutecznej komunikacji tych informacji menedżerom i pracownikom. W zarządzaniu dokonaniami skuteczna komunikacja jest realizowana z wykorzystaniem kart dokonań, kokpitów menedżerskich oraz różnorodnych form raportów.

\section{Projektowanie systemu zarządzania dokonaniami dla spółki handlowej}

Przedsiębiorstwo, dla którego został zaprojektowany i aktualnie jest wdrażany system zarządzania dokonaniami, to jedna z największych spółek w Europie Środkowej i Wschodniej, prowadząca przede wszystkim działalność handlową. Z uwagi na to, że spółka jest notowana na Giełdzie Papierów Wartościowych w Warszawie autorzy nie mogą szczegółowo charakteryzować profilu jej działalności i podać jej nazwy, natomiast mogą odnieść się bezpośrednio do problematyki projektowania i wdrażania systemu zarządzania dokonaniami w niniejszym podmiocie, ponieważ od ponad roku wchodzą w skład zespołu, który jest za to odpowiedzialny.

Omawiane przedsiębiorstwo prowadzi swoją działalność jako grupa kapitałowa, która posiada aktualnie około tysiąca salonów sprzedaży. Sieć sprzedaży podzielonych na dwie główne grupy:

1) Sklepy własne $z$ czterema kanałami geograficznymi: 
- Polska - około 40\% działalności grupy,

- Europa Środkowa i Wschodnia: Czechy, Słowacja, Węgry, Słowenia, Chorwacja i Bułgaria,

- Europa Zachodnia: Niemcy i Austria,

- Pozostałe: Rosja, Serbia.

2) Franczyza:

- Rumunia, Litwa, Łotwa, Estonia, Ukraina, Mołdawia.

Ponadto spółka posiada dynamicznie się rozwijający kanał e-commerce, który stanowi już około 17\% działalności grupy i działa w jedenastu krajach.

Strategia prezentowanej spółki koncentruje się na jej dynamicznym rozwoju i wchodzeniu na nowe rynki przede wszystkim Europy Środkowej i Wschodniej. Spółka działa na wysoce konkurencyjnym rynku odzieży i obuwia, a do jej strategicznych czynników sukcesu należy zaliczyćl:

- posiadanie rozbudowanej sieci sprzedaży w siedemnastu krajach europejskich ze sklepami o atrakcyjnej dla klienta lokalizacji,

- dynamiczne rozwijanie kanału sprzedaży internetowej (e-commerce),

- wykorzystanie koncepcji fast fashion, czyli dostarczanie klientom kilku tysięcy różnicowanych modeli w krótkich seriach, atrakcyjnych cenowo w każdym sezonie,

- posiadanie w portfolio sprzedaży produktów własnych i marek obcych,

- logistykę oraz know-how w zakresie projektowania i budowania kolekcji na najwyższym poziomie.

Z uwagi na dynamiczny rozwój spółki i wzrastające zapotrzebowanie na istotne informacje wspomagające proces decyzyjny na różnych szczeblach organizacji, zarząd w 2016 roku podjął decyzję o zaprojektowaniu i wdrożeniu nowego systemu zarządzania dokonaniami. Jego fundamentem jest nowoczesny system BI z hurtownią danych i systemami wspomagającymi.

Analizując literaturę przedmiotu z zakresu zarządzania dokonaniami, można zauważyć różnorodne podejścia do procesu projektowania i wdrażania tego systemu. Proces projektowania i wdrożenia jest zawsze dostosowywany do specyfiki konkretnego przedsiębiorstwa i musi być zindywidualizowany. $Z$ reguły można podzielić go na dwie podstawowe fazy [Kowalewski 2012]:

I. gruntowną analizę przedsiębiorstwa i zaprojektowanie odpowiedniego systemu zarządzania dokonaniami,

II. wdrożenie zaprojektowanego systemu i jego permanentne udoskonalanie oraz dostosowywanie do zmieniającego się przedsiębiorstwa.

W ramach dwóch głównych faz można wydzielić szczegółowe etapy, które są kluczowe z punktu widzenia efektywności funkcjonowania systemu w przedsiębiorstwie. Zalicza się do nich [opracowanie własne na podstawie: Parmenter 2010, s. 42; Michalak 2008, s. 172; Nita 2014, s. 45]:

\footnotetext{
1 Informacje pochodzą ze strony internetowej spółki oraz jej materiałów wewnętrznych.
} 
1) zaangażowanie i wsparcie kierownictwa wyższego szczebla,

2) zorganizowanie zespołu odpowiedzialnego za przygotowanie i wdrożenie systemu,

3) promocja opracowywanego systemu zarządzania dokonaniami wśród pracowników,

4) analiza strategii, oczekiwań kluczowych interesariuszy oraz głównych procesów przedsiębiorstwa,

5) identyfikacja aktualnych czynników sukcesu,

6) wybór adekwatnych narzędzi IT,

7) zaprojektowanie właściwych zestawów mierników,

8) opracowanie systemu raportowania wewnętrznego,

9) opracowanie systemu szkoleń dla pracowników,

10) racjonalne powiązanie $z$ systemem motywacyjnym przedsiębiorstwa,

11) wdrożenie systemu i ciągła praca nad jego udoskonalaniem.

Podobną procedurę wybrano w omawianej spółce. Na samym początku prac zorganizowano zespół odpowiedzialny za system zarządzania dokonaniami. Następnie w ramach kilku spotkań zarząd bardzo precyzyjnie zdefiniował swoje oczekiwania dotyczące funkcjonalności i wykorzystania systemu zarządzania dokonaniami. Wybrano też narzędzia IT do tego projektu z systemem Business Intelligence. Wskazano na kilka kluczowych kwestii:

- powiązanie strategii z zarządzaniem operacyjnym,

- pozyskiwanie, przechowywanie, przetwarzanie, analizowanie ogromnych zbiorów danych pochodzących z różnorodnych systemów przedsiębiorstwa oraz z zewnątrz, skuteczna transformacja posiadanych danych w wartościowe informacje wspierające procesy decyzyjne,

- ciągłe udoskonalanie strategii, procesów i obszarów działalności w oparciu o informacje pochodzące $\mathrm{z}$ systemu,

- wsparcie informacyjne na poziomie strategicznym i operacyjnym, a także odpowiednia komunikacja informacji z wykorzystaniem kokpitów menedżerskich i raportów.

Z uwagi na wielkość i złożoność grupy kapitałowej projekt podzielono na etapy i wyraźnie określone jego priorytety. Ustalono, że oprócz poziomu strategicznego, obejmującego całą grupę kapitałową oraz jej poszczególne spółki, system ma wspomagać informacyjnie na poziomie strategicznym i operacyjnym poszczególne obszary funkcjonowania grupy. Są to:

1) sprzedaż

2) raportowanie zarządcze dla najwyższych władz grupy,

3) zarządzanie produktem,

4) HR,

5) alokacja,

6) zakupy,

7) e-commerce, 
8) logistyka (reklamacje, zarządzanie transportem, zwroty posezonowe, import/eksport, przyjęcia),

9) marketing,

10) księgowość,

11) umowy.

Zarząd wskazał na dział sprzedaży jako obszar pierwszy, priorytetowy, a zarazem testowy dla całego systemu zarządzania dokonaniami. Procedura projektowania i wdrażania zarządzania dokonaniami dla działu sprzedaży zostanie przedstawione w kolejnym rozdziale.

\section{Projektowanie i wdrażanie systemu zarządzania dokonaniami w spółce handlowej na przykładzie działu sprzedaży}

Dział sprzedaży w omawianym podmiocie jest odpowiedzialny za funkcjonowanie i wyniki całej sprzedaży detalicznej, czyli podlega mu około tysiąca salonów sprzedaży należących do grupy kapitałowej, które funkcjonują w siedemnastu krajach. $\mathrm{W}$ procesie projektowania i wdrażania zarządzania dokonaniami dla sprzedaży zespół odbył szereg spotkań z menedżerami działu, w ramach których precyzyjnie przeanalizowano i zdefiniowano potrzeby informacyjne. Przede wszystkim zebrano, zaktualizowano i dokonano hierarchizacji mierników dokonań oraz raportów, które są wykorzystywane w tym obszarze działalności grupy kapitałowej. Ponadto zdefiniowano źródła danych, które będą zasilały hurtownię danych i stanowiły podstawę obliczenia mierników i tworzenia raportów. W tabeli 1 przedstawiono kluczowe mierniki dokonań opracowane dla działu sprzedaży.

Kluczowe mierniki dokonań działu sprzedaży stanowią podstawę jego raportowania zarządczego. Do wymienionych kluczowych mierników dokonań zostały dodane mierniki uzupełniające, do których zaliczono:

- sprzedaż vs. plan,

- średnia wartość paragonu,

- średnia wartość sztuki,

- średni traffic na sklep / dzień,

- realizacja budżetu powierzchni,

- średnia wartość sprzedaży sklepu / dzień,

- średnia liczba transakcji,

- poziom zwrotów,

- koszty pracowników (koszty wynagrodzeń / obrót),

- inwentaryzacja,

- procentowy udział sprzedanego towaru w cenach pierwszych,

- ilość sprzedanego towaru w cenach pierwszych,

- ilość aktywnych promocji,

- udziały \% rabatów w stanie sklepowym i sprzedaży. 
Tabela 1. Kluczowe mierniki dokonań dla działu sprzedaży

\begin{tabular}{|c|c|}
\hline Miernik dokonań & Formuła i częstotliwość obliczenia \\
\hline Przychody & $\begin{array}{l}\text { Suma przychodów osiągana w każdej ze spółek detalicznych grupy kapi- } \\
\text { tałowej. Przychody są obliczane od najniższego poziomu i agregowane do } \\
\text { góry, czyli pojedynczy sklep, region, dystrykt, spółka (kraj), grupa kapitało- } \\
\text { wa. Częstotliwość obliczania: dzienna. }\end{array}$ \\
\hline $\begin{array}{l}\text { Marża brutto } \\
\text { pierwsza }\end{array}$ & $\begin{array}{l}\text { Suma przychodów ze wszystkich spółek grupy kapitałowej obliczanych we- } \\
\text { dług tzw. ceny pierwszej (pierwotnej - bez żadnych rabatów) - koszty własne } \\
\text { sprzedanych towarów wszystkich spółek grupy (koszty zakupu + koszty } \\
\text { transportu). Marża brutto jest obliczana od najniższego poziomu i agregowa- } \\
\text { na do góry. Częstotliwość obliczania: dzienna. }\end{array}$ \\
\hline $\begin{array}{l}\text { Marża brutto } \\
\text { rzeczywista }\end{array}$ & $\begin{array}{l}\text { Suma przychodów ze wszystkich spółek grupy kapitałowej obliczanych } \\
\text { według tzw. ceny rzeczywistej (z uwzględnieniem stosowanych rabatów) } \\
\text { - koszty własne sprzedanych towarów wszystkich spółek grupy (koszty } \\
\text { zakupu + koszty transportu). Marża brutto jest obliczana od najniższego } \\
\text { poziomu i agregowana do góry. Częstotliwość obliczania: dzienna. }\end{array}$ \\
\hline Przychody $/ \mathrm{m}^{2}$ & $\begin{array}{l}\text { Przychody generowane przez dany sklep / liczbę } \mathrm{m}^{2} \text { powierzchni sklepu. } \\
\text { Przychody/m² są obliczane od najniższego poziomu i agregowane do góry, } \\
\text { czyli pojedynczy sklep, region, dystrykt, spółka (kraj), grupa kapitałowa. } \\
\text { Częstotliwość obliczania: dzienna. }\end{array}$ \\
\hline $\begin{array}{l}\text { Wzrost przychodu L4L } \\
(\%)\end{array}$ & $\begin{array}{l}\text { Procentowy wzrost przychodów w ujęciu miesięcznym lub kwartalnym ob- } \\
\text { liczany na sklepach, które działają dłużej niż rok bez jakichkolwiek zmian } \\
\text { (np. powierzchni). }\end{array}$ \\
\hline EBIT & $\begin{array}{l}\text { Wynik operacyjny, czyli marża brutto - koszty operacyjne (SG\&A) } \\
+ \text { - - saldo pozostałe przychody i koszty operacyjne. EBIT jest obliczany } \\
\text { od najniższego poziomu i agregowany do góry, czyli pojedynczy sklep, } \\
\text { region, dystrykt, spółka (kraj), grupa kapitałowa. Częstotliwość obliczania: } \\
\text { dzienna. }\end{array}$ \\
\hline Traffic & $\begin{array}{l}\text { Liczba wejść do sklepu klientów w danym dniu. Traffic jest obliczany } \\
\text { od najniższego poziomu i agregowany do góry, czyli pojedynczy sklep, } \\
\text { region, dystrykt, spółka (kraj), grupa kapitałowa. Częstotliwość obliczania: } \\
\text { dzienna. }\end{array}$ \\
\hline Konwersja sprzedaży & $\begin{array}{l}\text { Liczba wejść do sklepu klientów w danym dniu do liczby zrealizowanych } \\
\text { transakcji (paragonów). Miernik ten odnosi się bezpośrednio do skutecz- } \\
\text { ności sprzedaży i jest obliczany od najniższego poziomu i agregowany do } \\
\text { góry, czyli pojedynczy sklep, region, dystrykt, spółka (kraj), grupa kapitało- } \\
\text { wa. Częstotliwość obliczania: dzienna. }\end{array}$ \\
\hline Liczba sztuk/paragon & $\begin{array}{l}\text { Średnia liczba sztuk sprzedawanego towaru przypadająca na jeden paragon. } \\
\text { Miernik jest obliczany od najniższego poziomu i agregowany do góry, czyli } \\
\text { pojedynczy sklep, region, dystrykt, spółka (kraj), grupa kapitałowa. Często- } \\
\text { tliwość obliczania: dzienna. }\end{array}$ \\
\hline
\end{tabular}

Źródło: opracowanie własne na podstawie badanej jednostki.

Cechą charakterystyczną nowoczesnego systemu zarządzania dokonaniami jest możliwość tzw. drillowania (czyli wchodzenia na najbardziej szczegółowe poziomy w ramach poszczególnych mierników). Każdy z mierników ma określone podsta- 
wowe poziomy obliczania. Na przykład przychody są obliczane z częstotliwością dzienną na poziomie pojedynczego sklepu, regionu, dystryktu, kraju (spółki) oraz grupy kapitałowej. Jednak w sytuacjach tego wymagających, analizując przychody z danego dnia, system zarządzania dokonaniami z Business Intelligence daje możliwość dojścia do pojedynczej transakcji (paragonu), których dziesiątki tysięcy dziennie składają się na dzienne przychody całej grupy kapitałowej.

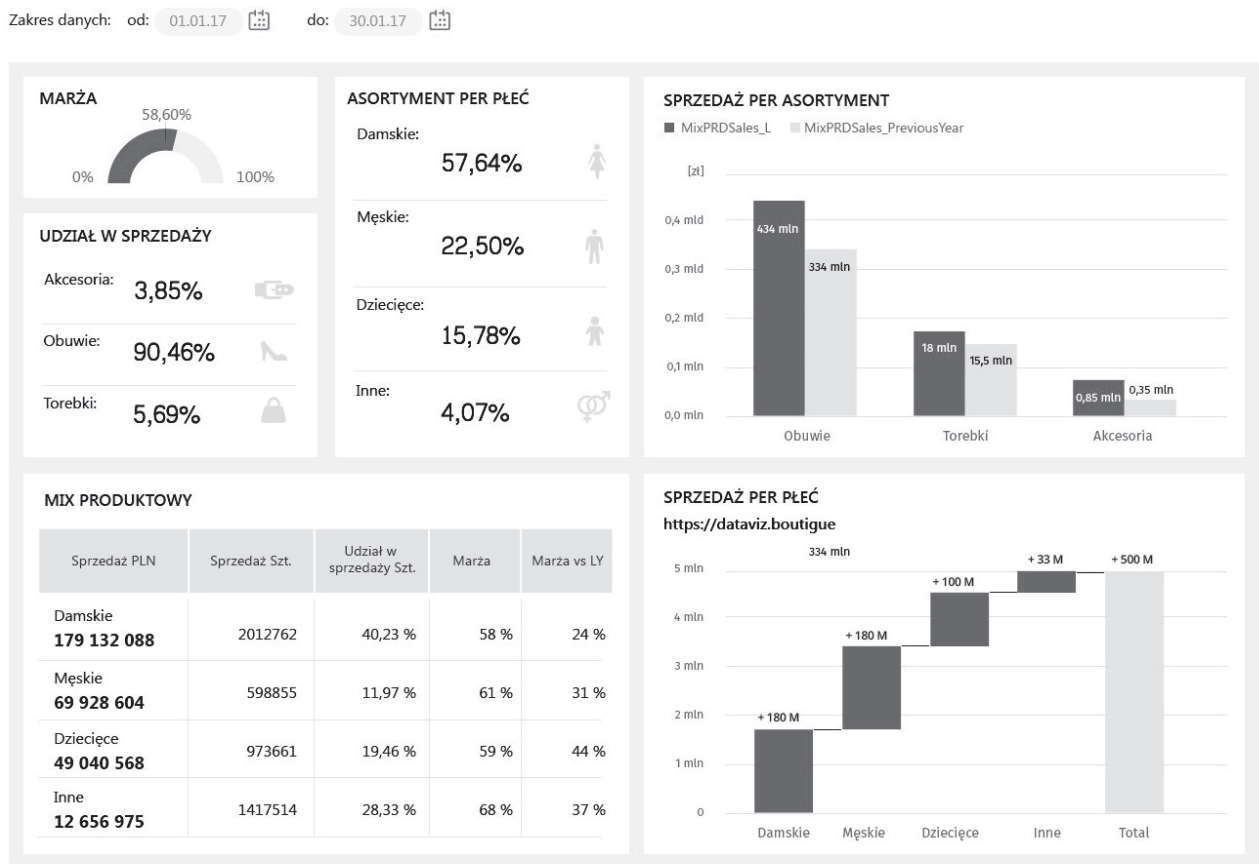

Rys. 1. Fragment kokpitu menedżerskiego działu sprzedaży (dane zmienione)

Źródło: opracowanie własne na podstawie badanej jednostki.

Następnie wszystkie mierniki określone dla działu sprzedaży zostały precyzyjnie opisane w zbiorczych kartach mierników, w których znalazły się następujące kategorie ich opisu:

- nazwa miernika,

- podstawowa formuła obliczenia,

- poziomy obliczania,

- warianty obliczenia,

- częstotliwość obliczania,

- aktualność prezentowanego miernika w systemie,

- punkt odniesienia (porównania) miernika lub wartość docelowa,

- jednostka miernika, 
- źródła danych,

- miejsce wykorzystania miernika (np. raport, kokpit),

- alerty związane z miernikiem,

- kluczowy użytkownik,

- osoby odpowiedzialne,

- powiązanie z systemem motywacyjnym.

Kolejnym etapem było opracowanie kokpitu menedżerskiego oraz raportów cyklicznych dla działu sprzedaży. Kokpity menedżerskie, nazywane również pulpitami menedżerskimi (dashboard), stanowią istotny składnik systemu BI, odpowiadający za skuteczną prezentację informacji wybranej grupie użytkowników przedsiębiorstwa.

Kokpity te są wykorzystywane w zarządzaniu dokonaniami szczególnie na potrzeby raportowania zarządczego. Kokpity menedżerskie wykorzystują zróżnicowane formy prezentacji, takie jak: mapy, tabele, wykresy, liczniki, kontrolki, ikony, komentarze oraz grupy dedykowanych mierników, w tym kluczowe mierniki dokonań. Innymi słowy, kokpit menedżerski stanowi optymalne rozwiązanie scalające raportowanie i analitykę, przy czym można wyróżnić kokpity statyczne i dynamiczne (interaktywne) umożliwiające drążenie, filtrowanie czy agregowanie danych oraz zmianę układu kokpitu [Ziuziański, Furmankiewicz 2015, s. 51, za: Kowalewski, Czyczerski 2018]. Na rysunkach 1 i 2 zaprezentowano fragmenty złożonego kokpitu menedżerskiego działu sprzedaży.

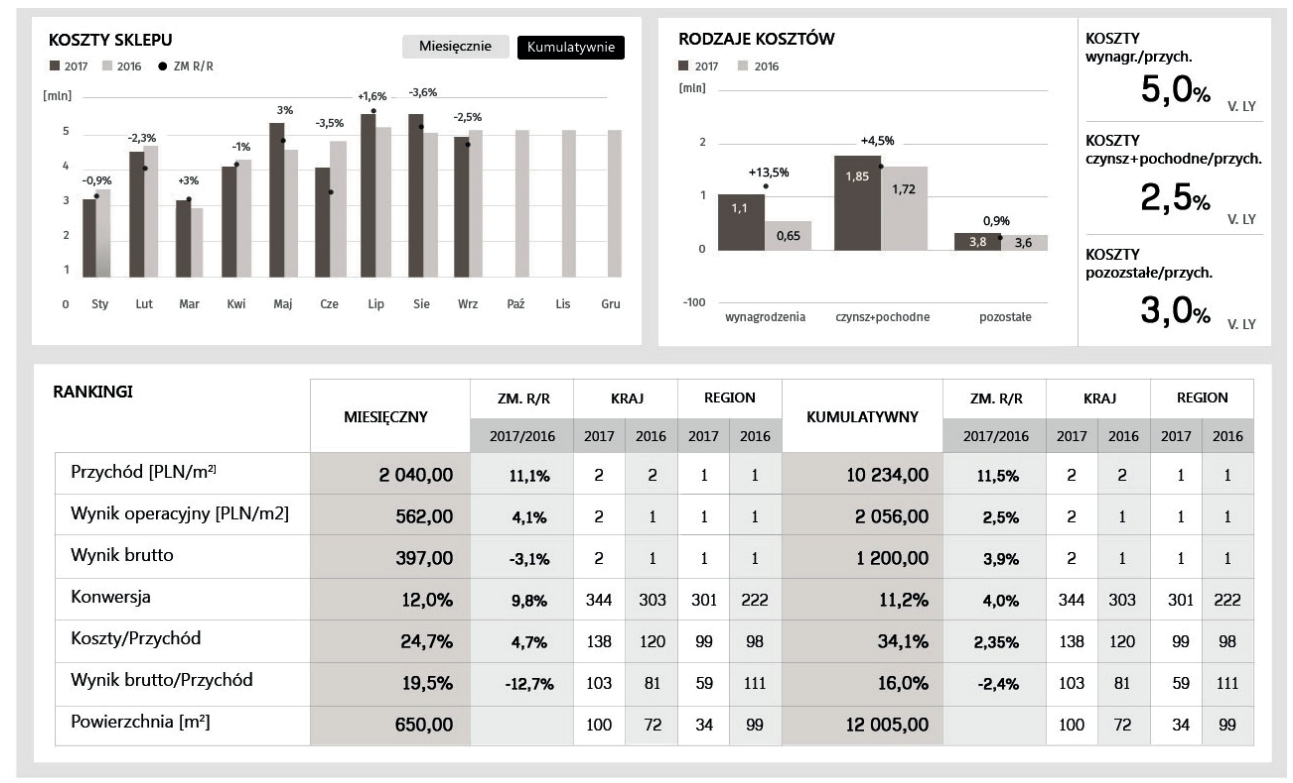

Rys. 2. Fragment kokpitu menedżerskiego działu sprzedaży (dane zmienione)

Źródło: opracowanie własne na podstawie badanej jednostki. 
Kolejnym krokiem było opracowanie i opisanie raportów cyklicznych, które będą automatycznie tworzone w systemie zarządzania dokonaniami. Lista raportów jest następująca:

1) meldunek sprzedaży - raport dzienny,

2) średnia dzienna + pogoda,

3) raport sklepów porównywalnych $\mathrm{L} 4 \mathrm{~L}$,

4) tygodniowy produktowy raport sprzedaży,

5) raport otwarć sklepów vs. plan,

6) raport rankingów efektywności sklepów,

7) raport traffic i konwersja sprzedaży,

8) raport najlepszych i najgorszych produktów,

9) raport miksu produktowego (analiza grup/departamentów/kategorii produktowych),

10) raport efektywności promocji i przecen,

11) analiza rynków / salonów / magazynu,

12) analiza rozmiarowa,

13) analiza efektywności regionalnych kierowników sprzedaży,

14) analiza efektywność dystryktów,

15) analiza elastyczności cenowej.

Podsumowując problematykę projektowania i wrażania systemu zarządzania dokonaniami dla działu sprzedaży grupy kapitałowej, należy podkreślić, że z uwagi na ograniczoną objętość artykułu autorzy odnieśli się tylko do wybranych zagadnień. Omawiany projekt jest niezwykle złożony i cały czas w trakcie realizacji. Jednak ukazuje on wyraźny trend, który uwydatnia się na rynku: coraz większy wpływ rozwiązań, narzędzi i systemów IT na system zarządzania współczesnego przedsiębiorstwa, szczególnie jest to widoczne w obszarze rachunkowości zarządczej i controllingu.

\section{Zakończenie}

Współczesne systemy zarządzania dokonaniami powinny wykorzystywać w pełnym zakresie możliwości systemów BI. Bez nich pozyskiwanie, przetwarzanie, analizowanie czy transformacja ogromnych zbiorów danych w użyteczne informacje wspierające procesy decyzyjne nie byłyby możliwa. Wykorzystanie BI ułatwia również skuteczniejszą prezentację tych informacji różnym odbiorcom z przedsiębiorstwa, wykorzystując różnorodne formy kokpitów menedżerskich, kart dokonań oraz raportów.

Kolejną cechą nowoczesnego systemu zarządzania dokonaniami jest automatyzacja większości procesów. Importowanie danych z różnorodnych systemów wewnętrznych i zewnętrznych, ich standaryzacja, przechowywanie, analiza oraz transformacja w użyteczne informacje, aktualizacja mierników w kokpitach i kartach dokonań, tworzenie różnorodnych raportów jest zautomatyzowane. Ponadto 
system BI w zarządzaniu dokonaniami oprócz samej hurtowni danych dysponuje innymi narzędziami i systemami, które umożliwiają efektywną pracę z ogromnym zbiorem danych. Zalicza się do nich: narzędzia do zapytań i raportowania, narzędzia drążenia (eksploracji) danych, analityczne przetwarzanie danych online (OLAP), narzędzia do projektowania raportów oraz warstwę wizualizacyjną systemu. Na koniec warto podkreślić jeszcze raz możliwości skutecznej komunikacji informacji w tym systemie. Kokpity menedżerskie, karty dokonań, różnorodne raporty wykorzystujące zróżnicowane formy prezentacji danych konstytuują niezwykle skuteczne, interaktywne narzędzie współczesnego zarządzania dokonaniami, ukierunkowane na wartościową komunikację informacji w procesach decyzyjnych.

\section{Literatura}

Anthony R.N., Hawkins D.F., Merchant K.A., 2011, Accounting Text and Cases, Thirteenth Edition, McGraw-Hill International Edition, New York.

Broadbent J., Laughlin R., 2009, Performance management systems: A conceptual model, Journal of Management Accounting Research, 20.

Cokins G., 2009, Performance Management. Integrating Strategy Execution, Methodologies, Risk, And Analytics, John Wiley \& Sons, Inc., Hoboken.

Czyczerski M., 2016, Rola przywództwa w zarządzaniu dokonaniami, PN Uniwersytetu Ekonomicznego we Wrocławiu, nr 442.

Eckerson W.W., 2006, Performance Dashboards: Measuring, Monitoring, and Managing Your Business, John Wiley \& Sons, Hoboken.

Hammer M., 2001, The Agenda: What Every Business Must Do to Dominate the Decade, Crown Business, New York.

Kowalewski M., 2012, Systemy pomiaru dokonań przedsiębiorstwa, [w:] Nowaka E. (red.), Pomiar i raportowanie dokonań przedsiębiorstwa, Wyd. CeDeWu, Warszawa.

Kowalewski M., 2016, Pomiar dokonań przedsiębiorstwa, [w:] Nowak E. (red.), Zarządzanie dokonaniami w organizacjach, Polskie Wydawnictwo Ekonomiczne SA, Warszawa.

Kowalewski M., 2018, Zarządzanie dokonaniami w grupach kapitałowych, [w:] Nowaka E. (red.), Rachunkowość zarządcza w grupach kapitałowych, CeDeWu, Warszawa.

Kowalewski M., Czyczerski M., 2018, Kokpity menedżerskie $i$ Business Intelligence $w$ zarzadzaniu dokonaniami przedsiębiorstwa, Finanse, Rynki Finansowe, Ubezpieczenia (w druku).

Łada M., Burnet-Wyrwa W., 2015, Rozwój samoobstugowych systemów Business Intelligence a zmia$n y$ w rachunkowości zarzadczej, Studia Ekonomiczne. Zeszyty Naukowe Uniwersytetu Ekonomicznego w Katowicach, nr 245.

Melnyk S.A., Bititci U., Platts K., Tobias J., Andersen B., 2014, Is performance measurement and management fit for the future?, Journal of Management Accounting Research, 25.

Michalak J., 2008, Pomiar dokonań od wyniku finansowego do Balanced Scorecard, Difin, Warszawa.

Negash S., 2004, Business Intelligence, Communications of the Association for Information Systems, vol. 13, Article 15, http://aisel.aisnet.org/cais/vol13/iss1/15 (7.03.2018)

Nesterak J., 2010, Business Intelligence jako narzędzie wspierające decyzje zarządcze w firmie, Zeszyty Naukowe, Prace z Zakresu Ekonomiki i Organizacji Przedsiębiorstw, nr 836.

Nesterak J., 2015, Controlling zarzadczy Projektowanie $i$ wdrażanie, Wolters Kluwer SA, Warszawa. 
Nita B., 2009, Rola rachunkowości zarządczej we wspomaganiu zarządzania dokonaniami przedsiębiorstwa, Wyd. Uniwersytetu Ekonomicznego we Wrocławiu, Wrocław.

Nita B., 2014, Sprawozdawczość zarządcza. Analizy i raporty wewnętrzne w controllingu, Wydawnictwo Naukowe PWN, Warszawa.

Olszak C.M., Ziemba E., 2007, Approach to building and implementing Business Intelligence Systems, Interdisciplinary Journal of Information, Knowledge, and Management, no. 2.

Parmenter D., 2010, Key Performance Indicators, Wiley \& Sons, New Jersey.

Wierzbiński M., 2016a, System zarzadzania dokonaniami a model biznesowy, Prace Naukowe Uniwersytetu Ekonomicznego we Wrocławiu, nr 442.

Wierzbiński M., 2016b, Performance management in a water and sewerage company, Prace Naukowe Uniwersytetu Ekonomicznego we Wrocławiu, nr 434.

Ziuziański P., Furmankiewicz M., 2015, Kokpit menedżerski jako narzędzie do wizualizacji danych w kontekście zarządzania wiedza w organizacji, Ekonomia i Zarządzanie (Economics and Management), $\mathrm{nr} 1$. 